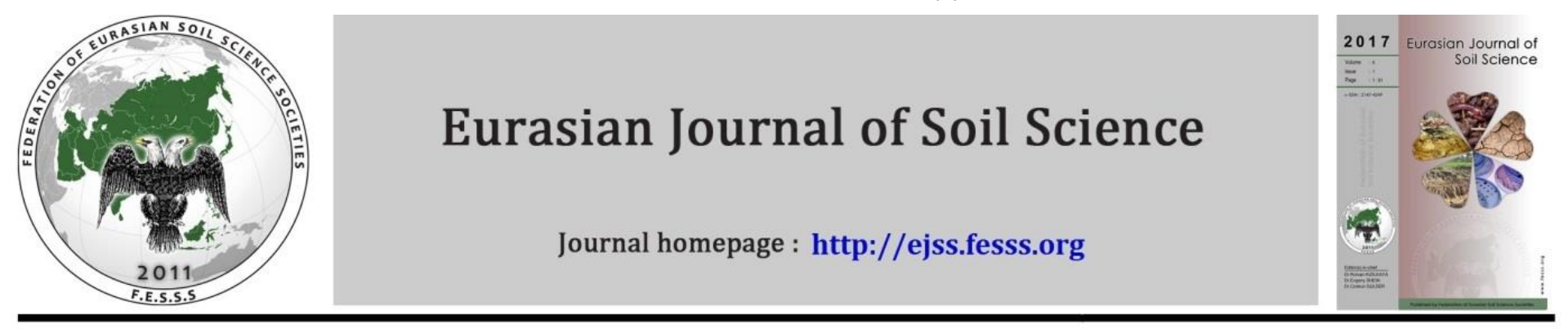

\title{
Persistence of myclobutanil and its impact on soil microbial biomass $C$ and dehydrogenase enzyme activity in tea orchard soils
}

\author{
Dongdong Zhang a, Yunli Wu a, Xiaolin Zhang a, Youfeng Zhu a,b,* \\ ${ }^{a}$ MOE Key Lab of Environmental Remediation and Ecosystem Health, College of Environmental and Resource Sciences, \\ Zhejiang University, Hangzho, China \\ b Zhejiang Provincial Key Laboratory of Organic Pollution Process and Control, College of Environmental and Resource \\ Sciences, Zhejiang University, Hangzho, China
}

\section{Article Info}

Received : 17.06 .2016

Accepted : 14.10 .2016

\begin{abstract}
Persistence of the fungicide myclobutanil in three tea orchard soils with different cultivating ages, neighboring wasteland and forest soils, and its influence on microbial activities in 2- and 50-year-oldtea orchard soils at three rates were studied in the laboratory. Dissipation data fitted well to first-order kinetic equation, except for sterilized treatments, in which neglected dissipation of myclobutanil was observed. At $25^{\circ} \mathrm{C}$, the dissipation half-lives $\left(\mathrm{DT}_{50}\right)$ at level of $1 \mathrm{mg} \mathrm{kg}^{-1}$ were in the range of 15.07 69.32 days under non-flooded condition, significantly lower than flooded condition ( $p<$ 0.05), indicating that dissipation of myclobutanil was mainly driven by soil microorganisms under aerobic condition. Dissipation rate was significantly increased at $40^{\circ} \mathrm{C}$ compared to those at $4^{\circ} \mathrm{C}$ and $25^{\circ} \mathrm{C}$ for all five soils $(\mathrm{p}<0.05)$. Under all incubation conditions, $\mathrm{DT}_{50}$ were lowest in 50-year-old tea orchard soil $(\mathrm{p}<0.01)$. Correlation analysis between $\mathrm{DT}_{50}$ in tea orchard soils and soil properties showed that soil microbial biomass carbon was negatively correlated with $\mathrm{DT}_{50}$ under $25^{\circ} \mathrm{C}$ and $60 \%$ water holding capacity $(\mathrm{p}<0.05)$. In general, soil microbial biomass carbon and dehydrogenase activity decreased as the concentration of myclobutanil and incubation time increased except $0.1 \mathrm{mg} \mathrm{kg}^{-1}$ spiked soils, in which soil dehydrogenase activity was stimulated after 10 days incubation.
\end{abstract}

Keywords: Myclobutanil, tea orchard soil, dissipation kinetic, soil microbial biomass, microbial activity.

(c) 2017 Federation of Eurasian Soil Science Societies. All rights reserved

\section{Introduction}

Myclobutanil, an important triazole fungicide used against powdery mildew of cereal, vegetables, and fruits, is registered in more than 40 countries worldwide (Anon., 1993; Kemmitt et al., 2008). It is also widely applied to tea orchard to prevent brown spot disease. The amended European Union legislation has set the maximum residue limits (MRLs) for myclobutanil in different agricultural products and the MRL for tea is $0.05 \mathrm{mg} \mathrm{kg}^{-1}$ (Regulation EU, 567/2016). Residues of myclobutanil in some crops and the soils in which they were grown have been found (Athanasopoulos et al., 2003). It was also detected in agricultural head water streams (Smiley et al., 2014) and rain (Vogel et al., 2008) in the US.

\footnotetext{
${ }^{*}$ Corresponding author.

MOE Key Lab of Environmental Remediation and Ecosystem Health, College of Environmental and Resource Sciences, Zhejiang University, Hangzhou 310058, China

Tel.: +8657188982953

E-mail address: zhuyoufeng73@zju.edu.cn

e-ISSN: 2147-4249 DOI: 10.18393 /ejss.286539
} 
Persistence of myclobutanil in different soils has been studied in laboratory and field conditions. The reported dissipation half-life ( $\mathrm{DT}_{50}$ ) values were from 11.0-19.2 days (Liu et al., 2009; Han et al., 2009; Wang et al., 2012) up to 574 days in anaerobic soil (WHO/FAO, 2014).The reasons to the varying $\mathrm{DT}_{50}$ values in soils need to be addressed. Study on composting and digestion at full-scale plants revealed that myclobutanil was moderately persistent to persistent (DT ${ }_{50}>70$ days) in aerobic soils and persistent in anaerobic soils (Kupper et al., 2008). Organic residue amendments increased persistence and significant relationship was observed between the sorption of myclobutanil by the soils and $\mathrm{DT}_{50}$ values $(\mathrm{p}<0.05)$ (Marín-Benito et al., 2014). Laboratory studies on the adsorption/desorption to soils indicated a low to moderate potential for vertical mobility (PPDB, 2011).

Tea (Camellia sinensis) is cultivated widely on acid red soils in the tropical and subtropical zones in China as an important economic crop (Wang et al., 2014) and also in more than 50 countries in the world with an annual production of approximately 4.7 million tons (Fang et al., 2014). Xue et al. (2006) reported that the $\mathrm{pH}$ value of tea orchard soil gradually decreases, and soil organic matter, soil $\mathrm{N}$ and $\mathrm{P}$ contents incease with the increase of cultivating ages. Therefore, tea orchard soils with different cultivating ages provide good samples to study the influence of soil physicochemical and biological properties on myclobutanil persistence.

Previous papers reported that triazole fungicides can have non-target effects on soil microbial communities (Yen et al., 2009; Muñoz-Leoz et al., 2011; Zhang et al., 2014). However, there are few studies on the impact of myclobuanil on soil microbial biomass and activity (Marín-Benito et al., 2014). To ascertain myclobutanil persistence and its impact soil microorganisms, 2-, 50-, and 100-year-old tea orchard soils, and neighboring wasteland and forest soils were collected. The two main objectives of this study were to: (1) evaluate the persistence of myclobutanil in tea orchard soils and the effect of soil properties and incubation conditions, i.e., water content and temperature, on its persistence, (2) investigate the influence of the fungicide spiked at three levels on soil microbial biomass carbon $\left(C_{\text {mic }}\right)$ and dehydrogenase activity (DHA).

\section{Material and Methods}

\section{Soil samples}

The soil samples were collected from five sampling plots that were randomly chosen within a 2-year-oldtea orchard, a 50-year-old tea orchard and a 100-year-old tea orchard in Hangzhou, China. To evaluate soil biochemistry and microbial properties as a function of land-use change and management practice, neighboring wasteland and forest were also chosen as study sites. The wasteland in this red soil area was covered with sparse grasses. The 100-year-old forest, established on wasteland in 1914, was a mixed-conifer forest. From each sampling plot, 20 cores $(5 \mathrm{~cm}$ in diameter $\times 20 \mathrm{~cm}$ in length) were taken and mixed. All soils investigated were classified as red soils by the China Classification System (Ultisols in USA soil taxonomy). Soil samples transported on ice to the laboratory and passed through a $2 \mathrm{~mm}$ sieve to remove rocks and plant debris. Each bulked sample was then separated into two parts. One part was air-dried for chemical analysis (except that mineral-N was immediately analyzed), and another was stored at $4^{\circ} \mathrm{C}$ until the incubation experiment.

Soil $\mathrm{pH}$ was determined in a 1:2.5 soil/water ratio. Soil organic matter was measured according to the method of dichromate oxidation (Nelson and Sommers, 1982). Total nitrogen was determined by Kjeldahl digestion (Keeney and Nelson, 1982), and ammonium and nitrate was extracted with $2 \mathrm{~mol} \mathrm{~L}^{-1} \mathrm{KCl}$ and determined colorimetrically in a continuous flow analyzer (SA5000, Skalar Inc., the Netherlands).

Available phosphorus analysis was undertaken following the method by Olsen and Sommers (Olsen and Sommers, 1982). Heavy metal analysis: Soils were digested with nitric $\left(\mathrm{HNO}_{3}\right)$, hydrofluoric (HF), and hydrochloric $(\mathrm{HCl})$ acid. Heavy metals $(\mathrm{Cr}, \mathrm{Ni}, \mathrm{Cu}, \mathrm{Zn}, \mathrm{Cd}$, and $\mathrm{Pb}$ ) were analyzed with Inductively Coupled Plasma-Mass Spectrometry (ICP-MS) (Agilent 7700X, USA).

The selected soil characteristics and heavy metal contents are summarized in Table 1 . With the increase of tea-orchard age, the $\mathrm{pH}$ value decreases, and SOM, nitrogen and phosphorous contents increase, except that $C_{\text {mic }}$ is highest in 50-year tea orchard soil. According to the Environmental Quality Standard for Soils of China (GB 15618-1995), the concentrations of $\mathrm{Cr}, \mathrm{Cu}$, and $\mathrm{Ni}$ were generally at low levels. While in 50-year tea orchard soil and wasteland soil, the concentrations of Cd were 0.29 and $0.24 \mathrm{mg} \mathrm{kg}^{-1}$, respectively, and over Grade I. In 100-year tea orchard soil and forest soil, $\mathrm{Pb}$ levels were over Grade I. The concentrations of $\mathrm{Zn}$ in all soil samples were over Grade II. 
Table 1.Physico-chemical and biological properties parameters and heavy metal contents in five studied soils

\begin{tabular}{|c|c|c|c|c|c|c|c|c|c|c|c|c|c|}
\hline \multirow{2}{*}{$\begin{array}{l}\text { Soil } \\
\text { samples }\end{array}$} & \multirow{2}{*}{$\begin{array}{c}\mathrm{pH} \\
(1: 2.5)\end{array}$} & \multirow{2}{*}{$\begin{array}{c}\text { SOM } \\
\left(\mathrm{g} \mathrm{kg}^{-1}\right)\end{array}$} & $\mathrm{NO}_{3}-\mathrm{N}$ & $\mathrm{NH}_{4}^{+}-\mathrm{N}$ & $\mathrm{TN}$ & $C_{\text {mic }}$ & $\mathrm{A}-\mathrm{P}$ & \multicolumn{3}{|c|}{ Heavy metal contents } & \multicolumn{3}{|c|}{ ( mg kg-1 dry weight) } \\
\hline & & & \multicolumn{5}{|c|}{$\left(\mathrm{mg} \mathrm{kg}^{-1}\right)$} & $\mathrm{Cr}$ & $\mathrm{Cu}$ & $\mathrm{Ni}$ & $\mathrm{Zn}$ & $\mathrm{Cd}$ & $\mathrm{Pb}$ \\
\hline 2-year & 4.57 & 11.26 & 11.72 & 5.49 & 1.31 & 244.66 & 3.71 & 40.74 & 10.24 & 11.00 & 316.11 & ND & 29.24 \\
\hline 50-year & 4.00 & 33.26 & 13.54 & 16.83 & 2.93 & 565.78 & 56.68 & 31.06 & 15.28 & 10.89 & 287.77 & 0.29 & 31.35 \\
\hline 100-year & 3.52 & 61.13 & 57.96 & 22.06 & 5.61 & 341.44 & 246.02 & 38.09 & 20.34 & 10.98 & 298.74 & 0.18 & 36.35 \\
\hline Forest & 4.11 & 76.51 & 17.18 & 19.49 & 5.11 & 349.56 & 22.96 & 37.62 & 11.05 & 9.41 & 211.76 & ND & 42.08 \\
\hline Wasteland & 5.34 & 8.09 & 5.76 & 3.08 & 0.86 & 121.66 & 5.10 & 41.01 & 12.50 & 11.55 & 254.19 & 0.24 & 33.14 \\
\hline
\end{tabular}

\section{Persistence of myclobutanil in soils}

Chromatography grade acetone and n-hexane were supplied by Sigma-Aldrich (Steinheim, Germany). An analytical standard of myclobutanil (> 99\%) was obtained from Dr. Ehrenstorfer GmbH (Augsburg, Germany). The incubation experiments are based on a modification of the reported procedures (Singh and Dureja, 2000; Dong et al., 2013). To test water content on persistence of myclobutanil, each soil sample (5 g) was adjusted to $60 \%$ and $125 \%$ water holding capacity (WHC), and pre-incubated for $48 \mathrm{~h}$ in the dark at $25^{\circ} \mathrm{C}$. Soil samples $(1 \mathrm{~g})$ was artificially spiked by $1 \mathrm{~mL}$ of $5 \mu \mathrm{g} \mathrm{mL}-1$ myclobutanil solution and set for $30 \mathrm{~min}$ under the hood until n-hexane was evaporated completely, and then added the rest soil to give a final concentration of $1 \mathrm{mg} \mathrm{kg}^{-1}$ soil. The sterilized controls (60\% WHC), unflooded (60\% WHC), and flooded $\left(125 \%\right.$ WHC) treatments were then incubated at $25^{\circ} \mathrm{C}$ in the dark.- To test the season effect on persistence of myclobutanil, unflooded treatments were also incubated at $4^{\circ} \mathrm{C}$ and $40^{\circ} \mathrm{C}$, respectively. Each treatment contained triplicate replicates. Soil moisture was regulated daily with sterile deionized water. Sampling was carried out after $0,2 \mathrm{~h}, 1,3,5$, and 10 days of incubation, and then stored at $-20^{\circ} \mathrm{C}$ for myclobutanil determination. For myclobutanil extraction, $25 \mathrm{~mL}$ of acetone and water (v:v/5:3) was added and shaked for $2 \mathrm{~h}$ at the speed of $200 \mathrm{r} \mathrm{min}^{-1}$ at $20 \pm 2^{\circ} \mathrm{C}$, and then centrifuged at $7000 \mathrm{r} \mathrm{min}^{-1}$ for $5 \mathrm{~min}$. This step was repeated twice by extraction with $10 \mathrm{~mL}$ of acetone and water. The extracts were concentrated until acetone was evaporated in a rotary evaporator, and the aqueous phase was extracted three times by ethyl acetate. The extracts were combined and dried over anhydrous $\mathrm{Na}_{2} \mathrm{SO}_{4}$, and then concentrated to near dryness in a rotary evaporator. The residue was dissolved again in $15 \mathrm{~mL}$ of n-hexane and transferred into $50 \mathrm{~mL} \mathrm{~K}-\mathrm{D}$ tube, adjusted the volume to $20 \mathrm{~mL}$. Sample was passed through $0.22 \mu \mathrm{m}$ filter before GC analysis.

The concentration of myclobutanil was determined by gas chromatography equipped with $\mathrm{Ni}^{63}$ electron capture detector (Agilent 7890N, USA) and a HP-5 column (30 m $\times 0.25 \mathrm{~mm}$ i.d. $\times 0.25 \mu \mathrm{m}$ film thickness) with ultrapure nitrogen as carrier gas and make-up gas at the flow rate of $1.0 \mathrm{~mL} \mathrm{~min}^{-1}$. The injector and detector temperature were $260^{\circ} \mathrm{C}$ and $300^{\circ} \mathrm{C}$, respectively. The oven temperature was programmed from $160^{\circ} \mathrm{C}$ (held for $1 \mathrm{~min}$ ) to $250^{\circ} \mathrm{C}$ (held for $3 \mathrm{~min}$ ) at $23^{\circ} \mathrm{C} \mathrm{min}^{-1}$, and then increased to $280^{\circ} \mathrm{C}$ at $4{ }^{\circ} \mathrm{C} \mathrm{min}{ }^{-1}$ (held for $10 \mathrm{~min}$ ). The injection volume was $1 \mu \mathrm{L}$. Compounds were identified by retention time using external standard and quantified using peak area integration. For every set of 10 samples, a procedural blank consisting of all reagents was run to check for interference and cross contamination. The recovery study was carried out three replicates at two spiked levels $\left(0.1\right.$ and $\left.1.0 \mathrm{mg} \mathrm{kg}^{-1}\right)$. Table 2 listed the mean recovery and relative standard deviation (RSD) of the method. The data confirmed the practicability of the analytical protocols herein in the determination of myclobutanil residues in all soil samples.

Table 2. Recoveries of myclobutanil in five studied soils at two spiking levels $(n=3)$

\begin{tabular}{ccccccc}
\hline \multirow{2}{*}{ Soil samples } & $\begin{array}{c}\text { Spiking levels } \\
\left(\mathrm{mg} \mathrm{kg}^{-1}\right)\end{array}$ & \multicolumn{4}{c}{ Recovery $/ \%$} & \multirow{2}{*}{ RSD/\% } \\
\cline { 3 - 5 } 2-year & 0.1 & 86.4 & 94.7 & 91.9 & 91 & 4.640 \\
& 1.0 & 99.3 & 90.1 & 98.6 & 96 & 5.335 \\
50-year & 0.1 & 115.7 & 101.8 & 118.5 & 112 & 7.985 \\
& 1.0 & 105.5 & 118.1 & 127.4 & 117 & 9.394 \\
\multirow{2}{*}{ 100-year } & 0.1 & 86.3 & 95.4 & 85.3 & 89 & 6.253 \\
& 1.0 & 87.2 & 91.3 & 97.5 & 92 & 5.636 \\
Forest & 0.1 & 87.8 & 95.2 & 81.0 & 88 & 8.071 \\
& 1.0 & 87.6 & 95.4 & 99.0 & 94 & 6.199 \\
Wasteland & 0.1 & 113.2 & 110.7 & 121.1 & 115 & 4.721 \\
& 1.0 & 109.4 & 117.6 & 127.0 & 118 & 7.463 \\
\hline
\end{tabular}




\section{Soil microbial activities}

Myclobutanil was applied to 2- and 50-year-old tea orchard soils at three rates $\left(0.1,1\right.$, and $10 \mathrm{mg} \mathrm{kg}^{-1}$, respectively). Soils unexposed to myclobutanil were used as controls. Each treatment contained triplicate replicates. The soil samples were prepared as described above. After 0,5 and 10 days of incubation, soil samples were transferred at $4^{\circ} \mathrm{C}$ for microbial biomass $\mathrm{C}$ and dehydrogenase activity analysis.

Soil $C_{\text {mic }}$ was determined by the chloroform fumigation-extraction method (Vance et al., 1987). Moist soil was fumigated with ethanol-free $\mathrm{CHCl}_{3}$ for $24 \mathrm{~h}$ at $25^{\circ} \mathrm{C}$ in sealed desiccators and extracted by shaking for $30 \mathrm{~min}$ with $0.5 \mathrm{M} \mathrm{K}_{2} \mathrm{SO}_{4}(40 \mathrm{~mL})$. The other soil of equal weight was not fumigated but extracted under the same condition. Soil $C_{\text {mic }}$ was calculated by the equation: $C_{\text {mic }}=2.64 \mathrm{E}_{\mathrm{C}}$, where $\mathrm{E}_{\mathrm{C}}=(\mathrm{C}$ extracted from fumigated soil) - (C extracted from non-fumigated soil), with 2.64 being a conversion factor.

Soil dehydrogenase activity was measured according to the method described by Tabatabai (Tabatabai, 1994). Five grams of soil sample was incubated in $5 \mathrm{~mL}$ of $0.1 \%$ 1, 3, 5-triphenyltetrazolium chloride (TTC) solution for $24 \mathrm{~h}$ at $37^{\circ} \mathrm{C}$ in the dark. Two drops of concentrated $\mathrm{H}_{2} \mathrm{SO}_{4}$ were added to stop the reaction. After incubation, triphenylformazan (TPF) was formed by the reduction of TTC. TPF was extracted with $5 \mathrm{~mL}$ of toluene and determined by spectrophotometry at $492 \mathrm{~nm}$. Blanks without soil were processed in the same manner.

Statistical analysis was performed by SPSS 16.0 (SPSS Inc., USA) using a one-way analysis of variance (ANOVA). The values were considered to be significantly different at a $95 \%$ confidence level. The values in the figures and tables are the average of triplicate data $(n=3) \pm$ standard deviations. All data are based on soil dry weight (DW).

\section{Results and Discussion}

\section{Persistence of myclobutanil}

Persistence of myclobutanil in three tea orchard soils with different cultivating ages, adjunct waste and forest soils under $4^{\circ} \mathrm{C}, 25^{\circ} \mathrm{C}, 40^{\circ} \mathrm{C}$, flooded and non-flooded conditions are presented in Table 3 and Figure 1.

Table3. Kinetic parameters of myclobutanil in soils under two WHC (60\% and $125 \%)$ and three incubation temperatures $(4$, 25 , and $40^{\circ} \mathrm{C}$, respectively).

\begin{tabular}{|c|c|c|c|c|c|c|}
\hline Soil samples & WHC $(\%)$ & Temperature & $k\left(d^{-1}\right)$ & $\mathrm{R}^{2}$ & $\mathrm{DT}_{50}(\mathrm{~d})$ & Degradation (\%)* \\
\hline \multirow{5}{*}{ 2-year } & \multirow{3}{*}{60} & $4^{\circ} \mathrm{C}$ & 0.029 & 0.9550 & $23.90^{\mathrm{a}, \mathrm{A}}$ & 23.84 \\
\hline & & $25^{\circ} \mathrm{C}$ & 0.031 & 0.9633 & $22.36^{\mathrm{a}, \mathrm{A}}$ & 26.47 \\
\hline & & $40^{\circ} \mathrm{C}$ & 0.044 & 0.9717 & $15.75^{\mathrm{b}, \mathrm{A}}$ & 36.59 \\
\hline & \multirow[t]{2}{*}{125} & $25^{\circ} \mathrm{C}$ & 0.014 & 0.9665 & $49.51^{* * *, \mathrm{~A}}$ & 12.66 \\
\hline & & $4^{\circ} \mathrm{C}$ & 0.045 & 0.9520 & $15.40^{\mathrm{a}, \mathrm{AB}}$ & 34.80 \\
\hline \multirow{4}{*}{ 50-year } & \multirow[t]{2}{*}{60} & $25^{\circ} \mathrm{C}$ & 0.046 & 0.9816 & $15.07^{a, B}$ & 35.44 \\
\hline & & $40^{\circ} \mathrm{C}$ & 0.069 & 0.9556 & $10.05^{\mathrm{b}, \mathrm{AB}}$ & 49.08 \\
\hline & \multirow[t]{2}{*}{125} & $25^{\circ} \mathrm{C}$ & 0.022 & 0.9543 & $31.23^{* * *}, \mathrm{~A}$ & 19.21 \\
\hline & & $4^{\circ} \mathrm{C}$ & 0.034 & 0.9627 & $20.39^{a, ~ B ~}$ & 27.27 \\
\hline \multirow[t]{4}{*}{ 100-year } & \multirow[t]{2}{*}{60} & $25^{\circ} \mathrm{C}$ & 0.035 & 0.9509 & $19.81^{\mathrm{a}, \mathrm{C}}$ & 28.49 \\
\hline & & $40^{\circ} \mathrm{C}$ & 0.052 & 0.9602 & $13.33^{\mathrm{b}, \mathrm{B}}$ & 40.70 \\
\hline & \multirow[t]{2}{*}{125} & $25^{\circ} \mathrm{C}$ & 0.018 & 0.9612 & $38.51^{* * *}, \mathrm{~A}$ & 17.02 \\
\hline & & $4^{\circ} \mathrm{C}$ & 0.020 & 0.9539 & $34.66^{\mathrm{a}, \mathrm{C}}$ & 17.16 \\
\hline \multirow{4}{*}{ Forest } & \multirow[t]{2}{*}{60} & $25^{\circ} \mathrm{C}$ & 0.020 & 0.9758 & $34.66^{\mathrm{a}, \mathrm{D}}$ & 17.25 \\
\hline & & $40^{\circ} \mathrm{C}$ & 0.030 & 0.9515 & $23.11^{\mathrm{b}, \mathrm{C}}$ & 26.90 \\
\hline & \multirow[t]{2}{*}{125} & $25^{\circ} \mathrm{C}$ & 0.011 & 0.9647 & $63.02^{* * *}, \mathrm{~A}$ & 10.55 \\
\hline & & $4^{\circ} \mathrm{C}$ & 0.010 & 0.9449 & $69.32^{\mathrm{a}, \mathrm{D}}$ & 9.57 \\
\hline \multirow{3}{*}{ Wasteland } & \multirow[t]{2}{*}{60} & $25^{\circ} \mathrm{C}$ & 0.010 & 0.9356 & $69.30^{\mathrm{a}, \mathrm{E}}$ & 9.44 \\
\hline & & $40^{\circ} \mathrm{C}$ & 0.016 & 0.9502 & $43.33^{\mathrm{b}, \mathrm{D}}$ & 15.21 \\
\hline & 125 & $25^{\circ} \mathrm{C}$ & 0.005 & 9376 & $138.64^{* * *, \mathrm{~B}}$ & 4.90 \\
\hline
\end{tabular}

Lower case letters indicate significant difference among different incubation temperatures under $60 \%$ WHCin the same soil $(\mathrm{p}<0.001)$. Upper case letters indicate significant difference among different soils under the same incubation conditions $(\mathrm{p}<$ $0.001)$. ${ }^{* *}$ indicates significant difference between $60 \%$ WHC and $125 \%$ WHC under $25^{\circ} \mathrm{C}(\mathrm{p}<0.001)$.

Dissipation data under different incubation conditions fitted well to first-order kinetic equation, $C_{\mathrm{t}}=C_{0} \mathrm{e}^{-k t}$, with correlation coefficient $\left(R^{2}\right)$ higher than 0.936 , except for sterilized treatments, in which only 0.08$1.41 \%$ of myclobutanil were dissipated after 10 days incubation. The degradation (D) was calculated 
according to the following equation: $\mathrm{D}=\left(C_{0}-C_{\mathrm{t}}\right) / C_{0} \times 100 \%$. In non-sterile soils, $4.90-49.08 \%$ of myclobutanil was degraded. Neglected dissipation was observed in sterilized treatments indicated microbial decomposition played a critical role in myclobutanil dissipation in studied soils. At $25^{\circ} \mathrm{C}$, the $\mathrm{DT}_{50}$ of myclobutanil at level of $1 \mathrm{mg} \mathrm{kg}^{-1}$ were in the range of 15.07-69.32 days under non-flooded condition, while under flooded condition, $\mathrm{DT}_{50}$ were from 31.23 days in 50-year-old tea orchard soil to 138.64 days in wasteland soil. The degradation rates decreased about 2 -fold as the WHC increased from $60 \%$ to $125 \%$ for all soils, which indicated that dissipation of myclobutanil was mainly driven by aerobic biotransformation. Our results are consistent with other triazole fungicides, hexaconazole (Singh and Dureja, 2000), penconazole and propiconazole (Singh and Dureja, 2009), which were found more persistent in soils under flooded than non-flooded conditions. However, a minor role of microorganisms in hexaconazole degradation was found (Singh and Dureja, 2000). Another study showed that the two soil water contents did not cause significant differences in dissipation rates between two triazole fungicides, triadimefon and propiconazole (Yen et al., 2009).
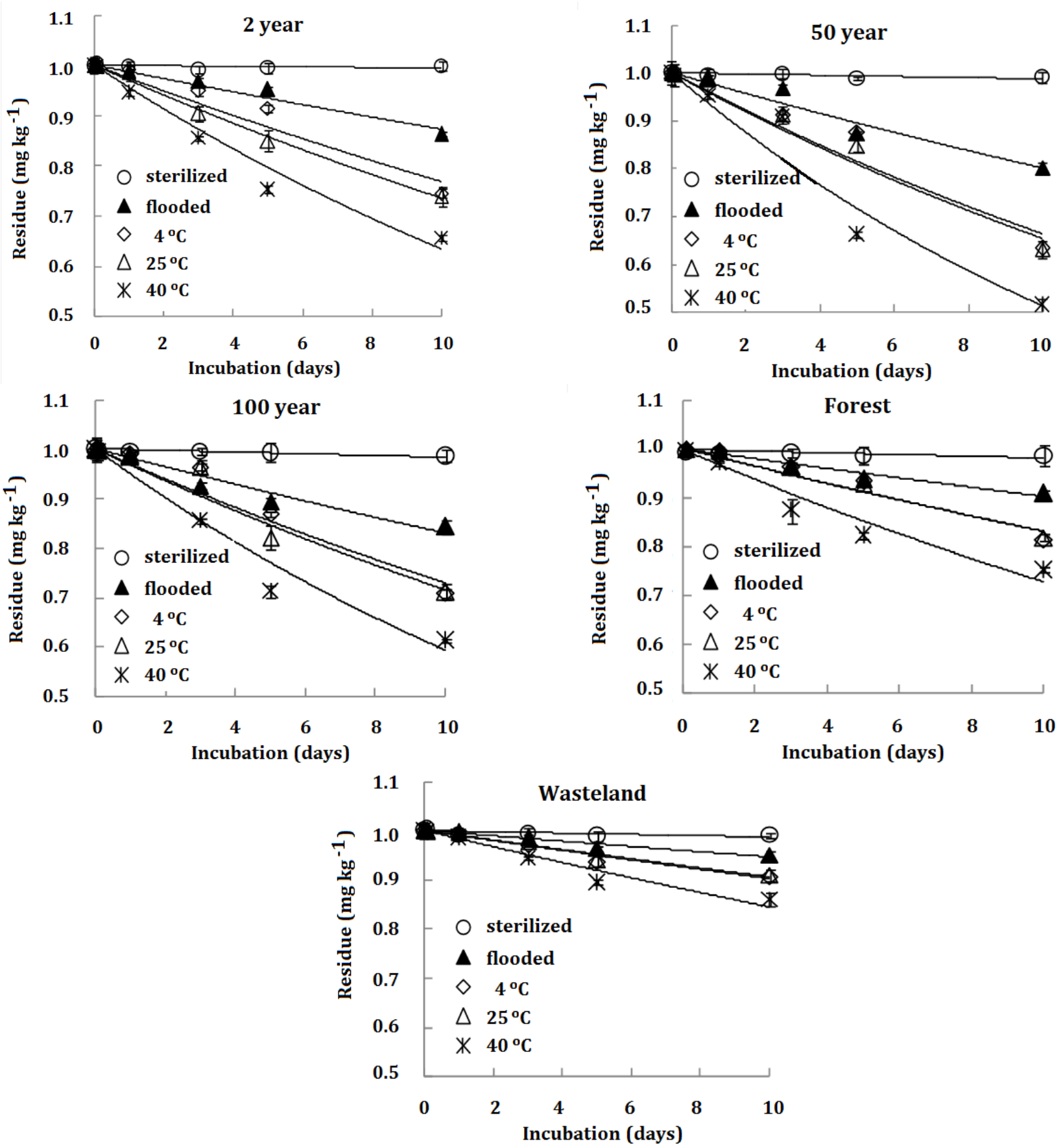

Figure 1. The dissipation of myclobutanil in five soils under sterilized $\left(25^{\circ} \mathrm{C}, 60 \% \mathrm{WHC}\right)$, unflooded $(60 \% \mathrm{WHC})\left(4^{\circ} \mathrm{C}\right.$, $25^{\circ} \mathrm{C}$, and $40^{\circ} \mathrm{C}$, respectively) and flooded $\left(25^{\circ} \mathrm{C}, 125 \% \mathrm{WHC}\right)$ conditions. 
Highest dissipation rate was observed in 50-year-old tea orchard soil, followed by 100- and 2-year tea orchard, and forest and wasteland soils, under all incubation conditions. Our result is in agreement with the findings on soil net nitrification study that the highest soil net nitrification was found in 50-year-old tea orchard, followed by 90- and 8-year-old tea orchard, and was significantly higher in the tea orchards compared to the wasteland and forest soils (Xue et al., 2006). Simple and multiple correlation analyses between $\mathrm{DT}_{50}$ and soil properties and heavy metal contents showed that $C_{\text {mic }}$ was negatively correlated with $\mathrm{DT}_{50}(\mathrm{p}<0.05)$ in three tea orchard soils under $25^{\circ} \mathrm{C}$ and $60 \%$ WHC. Previous paper also showed that degradation of three fungicides (azoxystrobin, tebuconazole, and chlorothalonil) was fastest in the high microbial biomass soil (Bending et al., 2007).

Influences of temperature and water content-on myclobutanil degradation are similar in five soils. Dissipation rate was significantly increased at $40^{\circ} \mathrm{C}$ compared to those at $4{ }^{\circ} \mathrm{C}$ and $25^{\circ} \mathrm{C}$ for all soils $(\mathrm{p}<0.05)$. The effects of temperature on the persistence on myclobutanil are in agreement with other triazole fungicides. Degradation of hexaconazole (Singh and Dureja, 2000) and triadimefon (Singh, 2005) were faster at $35^{\circ} \mathrm{C}$ than at $27^{\circ} \mathrm{C}$. Degradation rates of five triazole fungicides in two soils increased about 3 -fold as the temperature was increased from 5 to $18^{\circ} \mathrm{C}$ (Bromilow et al., 1999). The faster degradation of myclobutanil at higher temperature could be mainly due to a higher microbial activity. Wang et al. (2014) found that high temperature significantly increased fungal abundance from 86 to $274 \%$ under 55\% water holding capacity in a tea orchard soil. The volatilization in high temperature may have an insignificant effect on dissipation of myclobutanil, for myclobutanil is nonvolatile and has low mobility in soil. Myclobutanil exhibited negligible volatilization loss from golf course turfs (Wong et al., 2013).

\section{Soil microbial activities}

To assess the impact of application levels of myclobutanil on microorganisms in tea orchard soil, $C_{\text {mic }}$ and DHA were analyzed in 2- and 50-year tea orchard soils at three incubation time (Figure 2).
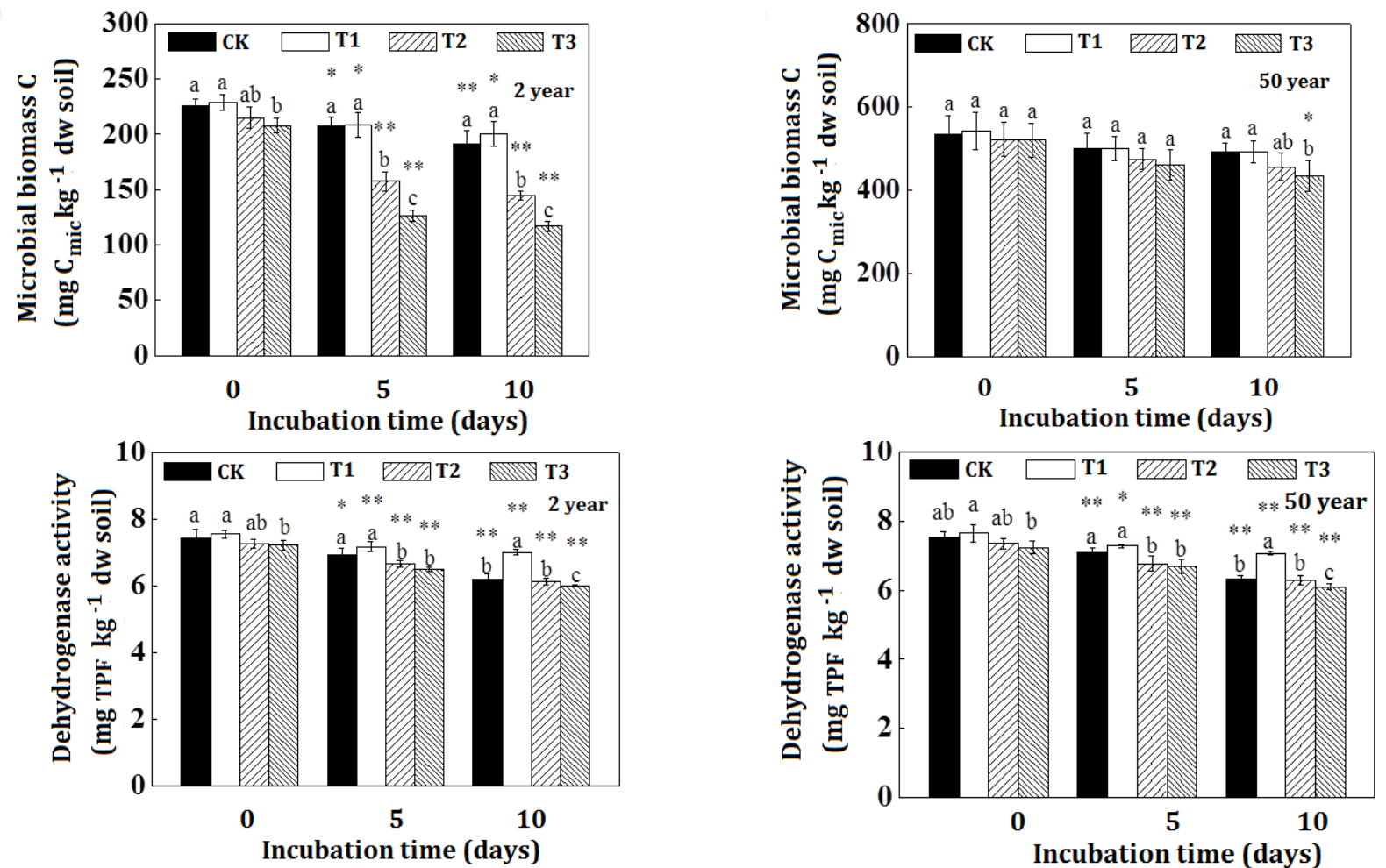

Figure 2. Effect of myclobutanil on soil microbial biomass $\mathrm{C}$ and dehydrogenase activity. Lower case letters indicate significantly difference among different spiking levels at the same incubation day $(\mathrm{p}<0.05)$. ${ }^{* *}(\mathrm{p}<0.01)$ and ${ }^{*}(\mathrm{p}<$ 0.05 ) indicate significant difference compared with day 0 at the same spiking levels of myclobutanil. CK, T1, T2, and T3 representing myclobutanil application levels at $0,0.1,1$, and $10 \mathrm{mg} \mathrm{kg}^{-1}$, respectively.

The $C_{\text {mic }}$ values ranged from 116.90 to $228.83 \mathrm{mg} \mathrm{kg}^{-1}$ and from 461.27 to $542.59 \mathrm{mg} \mathrm{kg}^{-1}$ in 2 - and 50 -yearold tea orchard soils, respectively. Similar results have been found in forest soils that $C_{\text {mic }}$ contents were higher in old-age forest soils compared to younger ones (Yan et al., 2009). No significant difference of $C_{\text {mic }}$ was observed in 50-year old tea orchard soil among different spiking levels at all incubation times. The $C_{\text {mic }}$ content only at $10 \mathrm{mg} \mathrm{kg}^{-1}$ spiked microcosms significantly decreased at day 10 compared with day 0 (p < 0.05). Inhibitory effect of myclobutanilon $C_{\text {mic }}$ in 2-year old tea orchard soil was aggravated with the increase 
of myclobutanil concentration and incubation time. Myclobutanil at $0.1 \mathrm{mg} \mathrm{kg}^{-1}$ level showed no significant

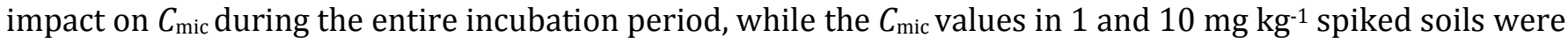
significantly lower than controls at day 5 and $10(\mathrm{p}<0.05)$. Compared with day 0 , both 1 and $10 \mathrm{mg} \mathrm{kg}^{-1} \mathrm{of}$ myclobutanil addition significantly inhibited $C_{\text {mic }}$ at day 5 and $10(\mathrm{p}<0.01)$. At day 10 , the $C_{\text {mic }}$ value in $10 \mathrm{mg}$ $\mathrm{kg}^{-1}$ of myclobutanil spiked 2-year old tea orchard microcosms was $43.8 \%$ lower than that in control soils, whereas in 50-year old tea orchard the $C_{\text {mic }}$ were only $16.52 \%$ lower. The results indicate that 50-year old tea orchard soil is more resistant to myclobutanil than 2-year old one. Previous papers on other triazole fungicides showed that tebuconazole application decreased $C_{\text {mic }}$ (Muñoz-Leoz et al., 2011; Zhang et al., 2014), but tended to recover at the end of the incubation when tetraconazole was applied at the recommended field rate (Zhang et al., 2014). In contrary, no significant impact on total microbial biomass was observed after tebuconazole addition in either the low or high OM/biomass soils (Bending et al., 2007).

The DHA values and inhibitory effect were similar in two soils. DHA values were both from 6.0 to $7.7 \mathrm{mg}$ TPF $\mathrm{kg}^{-1} \mathrm{DW}$ soil. DHA increased at $0.1 \mathrm{mg} \mathrm{kg}^{-1}$ application rate and inhibited at 1 and $10 \mathrm{mg} \mathrm{kg}^{-1}$ levels in both soils. In the $0.1 \mathrm{mg} \mathrm{kg}^{-1}$ amended soils, a significant increase of DHA was observed at day 10 . The maximum inhibition of DHA was observed in 1 and $10 \mathrm{mg} \mathrm{kg}^{-1}$ spiked soils at day 5 and tended to recover at day 10 compared with controls. Compared with day 0, DHA values were significantly lower in day 5 and 10 microcosms. Stimulation effect of myclobutanil on soil DHA has been reported at the application rate of $2 \mathrm{mg}$ $\mathrm{kg}^{-1}$ (Marín-Benito et al., 2014). For other triazole fungicides, DHA were significantly reduced by the addition of triadimefon at $1 \mathrm{mg} \mathrm{kg}^{-1}$ rate (Singh, 2005) and tebuconazole (Muñoz-Leoz et al., 2011). Therefore, as Hussain pointed out that a number of factors, such as, chemical nature and application levels of pesticides, soil microbial community structure, soil properties and conditions can contribute to divergent research findings (Hussain et al., 2009).

Our samples were incubated for only 10 days. The effect of myclobutanil on soil microbial biomass and activity could be long, as Yen's study found that after two fungicides were applied for 60 days and longer, the compositions of microbial communities were not recovered (Yen et al., 2009). Further work should be carried out with longer observation time to study the resistance and resilience of soil microbial communities to the fungicide application and especially the influence on narrow niche functions of fungal community.

\section{Conclusion}

Myclobutanil was readily aerobic degraded in studied soils with $\mathrm{DT}_{50}$ about 2-10 weeks. The dissipation rates of myclobutanil were clearly influenced by soil properties, temperature, and water content. Myclobutanil degradation was fastest in 50-year old tea orchard soil with the highest $C_{\text {mic }}$ content. Low myclobutanil level $\left(0.1 \mathrm{mg} \mathrm{kg}^{-1}\right)$ stimulated soil dehydrogenase activity, whereas high concentration $(1$ and $10 \mathrm{mg} \mathrm{kg}-1$ ) had negative effect on soil quality indicators which decreased significantly as myclobutanil concentration and incubation time increased. This study gains a better understanding of myclobutanil dissipation and its effect on microbial activities of this unique soil ecosystem, and helps management practices in tea orchard soils with different cultivating age.

\section{Acknowledgements}

We would like to thank Dr. Huaiying Yao for providing soil samples and some soil properties. The work was jointly supported by the National Natural Science Foundation of China (21477106) and Zhejiang Provincial Department of Education project (Y201226092).

\section{References}

Anon. 1993. Agriculture Canada. Decision Document: Myclobutanil. E93-01. Available at: http://publications.gc.ca/collections/Collection/H93-013-4-93-01E.pdf

Athanasopoulos, P.E., Pappas, C.J., Kyriakidis, N.V., 2003. Decomposition of myclobutanil and triadimefon in grapes on the vines and during refrigerated storage. Food Chemistry 82(3): 367-371.

Bending, G.D., Rodríguez-Cruz, M.S., Lincoln, S.D., 2007. Fungicide impacts on microbial communities in soils with contrasting management histories. Chemosphere 69(1): 82-88.

Bromilow, R.H., Evans, A.A., Nicholls, P.H., 1999. Factors affecting degradation rates of five triazole fungicides in two soil types: 1. Laboratory incubations. Pesticide Science 55(12): 1129-1134.

Fang, W.P., Meinhardt, L.W., Tan, H.W., Zhou, L., Mischke, S., Zhang, D., 2014. Varietal identification of tea (Camellia sinensis) using nanofluidic array of single nucleotide polymorphism (SNP) markers. Horticulture Research 35: 18.

Dong, F., Li, J., Chankvetadze, B., Cheng, Y., Xu, J., Liu, X., Li, Y., Chen, X., Bertucci, C., Tedesco, D., Zanasi, R., Zheng, Y., 2013. Chiral triazole fungicide difenoconazole: absolute stereochemistry, stereoselective bioactivity, aquatic 
toxicity, and environmental behavior in vegetables and soil. Environmental Science and Technology 47(7): 33863394.

Han, B.J., Chen, L.X., Peng, L.X. 2009. Degradation of four fungicides in tropical soils from Hainan, China. Journal of Food Agriculture and Environment 7(1): 197-200.

Hussain, S., Siddique, T., Saleem, M., Arshad, M., Khalid, A., 2009. Impact of pesticides on soil microbial diversity, enzymes, and biochemical reactions. Advances in Agronomy 102: 159-200.

Keeney, D.R., Nelson, D.W. , 1982. Nitrogen-inorganic forms. In: Methods of Soil Analysis, Part 2: Chemical and Microbiological Properties. $2^{\text {nd }}$ edition. Page A.L., Miller, R.H., Keeney, D.R., (Eds). American Society of Agronomy, Madison WI, USA. pp. 643-698.

Kemmitt, G.M., DeBoer, G., Ouimette, D., Iamauti, M., 2008. Systemic properties of myclobutanil in soybean plants, affecting control of Asian soybean rust (Phakopsora pachyrhizi). Pest Management Science 64(12): 1285-1293.

Kupper, T., Bucheli, T.D., Brändli, R.C., Ortelli, D., Edder, P. , 2008. Dissipation of pesticides during composting and anaerobic digestion of source-separated organic waste at full-scale plants. Bioresource Technology 99(17): 79887994.

Liu, X., Dong, F., Wang, X., Zheng, Y., 2009. The dissipation rates of myclobutanil and residue analysis in wheat and soil using gas chromatography-ion trap mass spectrometry. International Journal of Environmental Analytical Chemistry 89(13): 957-967.

Marín-Benito, J.M., Herrero-Hernández, E., Andrades, M.S., Sánchez-Martín, M.J., Rodríguez-Cruz, M.S., 2014. Effect of different organic amendments on the dissipation of linuron, diazinon and myclobutanil in an agricultural soil incubated for different time periods. Science of the Total Environment 476-477: 611-621.

Muñoz-Leoz, B., Ruiz-Romera, E., Antigüedad, I., Garbisu, C., 2011. Tebuconazole application decreases soil microbial biomass and activity. Soil Biology \& Biochemistry 43(10): 2176-2183.

Nelson, D.W., Sommers, L.E. 1982. Total carbon, organic carbon and organic matter. In: In: Methods of Soil Analysis, Part 2: Chemical and Microbiological Properties. 2ndedition. Page A.L., Miller, R.H., Keeney, D.R., (Eds). American Society of Agronomy, Madison WI, USA. pp. 539-580.

Olsen, S.R., Sommers, L.E., 1982. Phosphorus. In: Methods of Soil Analysis, Part 2: Chemical and Microbiological Properties. $2^{\text {nd }}$ edition. Page A.L., Miller, R.H., Keeney, D.R., (Eds). American Society of Agronomy, Madison WI, USA. pp. 403-430.

Pesticide Properties Database (PPDB). UK: University of Hertfordshire, 2011. Available at: http://sitem.herts.ac.uk/aeru/ppdb/en/Reports/478.htm

Regulation EU 567/ 2016/. Available at: http://eur-lex.europa.eu/legal-content/EN/TXT/?uri=CELEX:32016R0567.

Singh, N. 2005. Factors affecting triadimefon degradation in soils. Journal of Agricultural and Food Chemistry 53: 70-75.

Singh, N., Dureja, P. 2009. Effect of biocompost-amendment on degradation of triazoles fungicides in soil. Bulletin of Environmental Contamination and Toxicology 82(1): 120-123.

Singh, N., Dureja, P., 2000. Persistence of hexaconazole, a triazole fungicide in soils. Journal of Environmental Science and Health, Part B 35(5): 549-558.

Smiley Jr., P.C., King, K.W., Fausey, N.R. 2014. Annual and seasonal differences in pesticide mixtures within channelized agricultural head water streams in central Ohio. Agriculture Ecosystems \& Environment 193: 83-95.

Tabatabai, M.A. 1994. Soil Enzymes. In: Methods of Soil Analysis, Part 2: Chemical and Microbiological Properties. $2^{\text {nde }}$ dition. Weaver RW, (ed.). American Society of Agronomy, Madison WI, USA. pp. 903-947.

Vance, E.D., Brookes, P.C., Jenkinson, D.S. 1987. An extraction method for measuring soil microbial biomass C. Soil Biology \& Biochemistry 19(6): 703-707.

Vogel, J.R., Majewski, M.S., Capel, P.D. 2008. Pesticides in rain in four agricultural watersheds in the United States. Journal of Environmental Quality 37(3): 1101-1115.

Wang, H., Yang, J.P., Yang, S.H., Yang, Z.C., Lv, Y.M., 2014. Effect of a $10^{\circ} \mathrm{C}$-elevated temperature under different water contents on the microbial community in a tea orchard soil. European Journal of Soil Biology 62: 113-120.

Wang, X., Li, Y., Xu, G., Sun, H., Xu, J., Zheng, X., Wang, F., 2012. Dissipation and residues of myclobutanil in tobacco and soil under field conditions. Bulletin of Environmental Contamination and Toxicology 88(5): 759-763.

Wong, H., Haith, D.A., 2013. Volatilization of pesticides from golf courses in the United States: mass fluxes and inhalation health risks. Journal of Environmental Quality 42: 1615-1622.

WHO/FAO, 2014. Pesticide Residues in Food, Joint FAO/WHO meeting on pesticide residues. World Health Organization/Food and Agriculture Organization of the United Nations. Rome, Italy.

Xue, D., Yao, H.Y., Huang, C.Y. 2006. Microbial biomass, N mineralization and nitrification, enzyme activities, and microbial community diversity in tea orchard soils. Plant and Soil 288 (1): 319-331.

Yan, J., Zhang, D., Zhou, G., Liu, J. , 2009. Soil respiration associated with forest succession in subtropical forests in Dinghushan Biosphere Reserve. Soil Biology \& Biochemistry 41(5): 991-999.

Yen, J., Chang, J., Huang, P., Wang, Y. 2009. Effects of fungicides triadimefon and propiconazole on soil bacterial communities. Journal of Environmental Science and Health, Part B 44(7): 681-689.

Zhang, W., Xu, J., Dong, F., Liu, X., Zhang, Y., Wu, X., Zheng, Y. 2014. Effect of tetraconazole application on the soil microbial community. Environmental Science and Pollution Research 21(13): 8323-8332. 